\title{
Kütüphane İç Mekânlarının Evrensel Tasarım illkeleri Bağlamında Değerlendirilmesi: Karadeniz Teknik Üniversitesi Faik Ahmet Barutçu Kütüphanesi
}

\author{
Irem BEKAR ${ }^{1 *}$ (i) \\ ORCID 1: 0000-0002-6371-9958 \\ ${ }^{1}$ Karadeniz Teknik Üniversitesi, Mimarlık Fakültesi, iç̧ Mimarlık Bölümü, 61000, Trabzon, Türkiye. \\ *e-mail: irembekar@ktu.edu.tr
}

Öz

Değişen ve gelişen koşullar ile birlikte insanların mekânlardan beklentileri de etkilenmiş ve 'erişilebilirlik' kavramı daha da önem kazanmıştır. Özellikle kullanıcı kitlesi "herkes" olan yapıların tüm kullanıcıların ihtiyaçlarını karşılayabilir nitelikte olması gerekmektedir. Bu noktada ortaya çıkan 'evrensel tasarım' kavramı; kullanıcıların fiziksel özelliklerine veya kişisel yeterliliklerine bakmaksızın herkes tarafından kullanılabilmesine imkân sağlayan bütünsel bir yaklaşımdır. Çalışmada kullanıcı kitlesindeki çeşitlilik nedeniyle kütüphaneler ele alınmıştır. Kütüphanelerde birçok fonksiyonun yer alması sonucu oluşabilecek yapısal karmaşıklığa karşın; tasarımcının kullanıcı gruplarının tümünü göz önünde bulundurarak tasarım yapması beklenmektedir. Çalışmada Uluslararası Kütüphane Dernekleri ve Kurumları Federasyonu (IFLA) tarafından yayımlanan bildirgeler ışığında kütüphanelerde iç mekân tasarımının erişilebilirliğine yönelik veriler ortaya konmuş ve Karadeniz Teknik Üniversitesi Faik Ahmet Barutçu Kütüphanesi iç mekân tasarımında evrensel tasarım konusu irdelenmiştir. Böylece kütüphane yapılarında kullanım verimini arttırmak adına yol gösterecek öneriler sunularak evrensel tasarım ilkelerinin önemine dikkat çekmek amaçlanmaktadır.

Anahtar Kelimeler: Evrensel tasarım, engelsiz tasarım, kütüphane

\section{Evaluation of Library Interior Spaces Within the Context of Universal Design Principles: Karadeniz Technical University Faik Ahmet Barutcu Library}

\begin{abstract}
With the changing and developing conditions, people's expectations from the places have also been affected and the concept of 'accessibility' has gained more importance. Structures whose user is everyone must meet the needs of users. Universal design concept; It is a holistic approach that allows everyone to use it regardless of users' personal characteristics. In the study, libraries were discussed because of the diversity in the user base and the many functions in their structure. In the light of the declarations published by The International Federation of Library Associations and Institutions (IFLA), data on the accessibility of interior design in libraries were presented and the issue of universal design in the interior design of Karadeniz Technical University Faik Ahmet Barutçu Library was discussed. Thus, it is aimed to draw attention to the importance of universal design principles by offering suggestions to increase the efficiency of use in library buildings.
\end{abstract}

Keywords: Universal design, barrier-free design, library

Atıf/Citation: Bekar, i. (2021). Kütüphane i̇ç Mekânlarının Evrensel Tasarım İlkeleri Bağlamında Değerlendirilmesi: Karadeniz Teknik Üniversitesi Faik Ahmet Barutçu Kütüphanesi. Journal of Architectural Sciences and Applications, 6 (1), 178-194. DOI: 10.30785/mbud.875137 


\section{Giriş}

Değişen dinamiklerden ve gelişmelerden kaynaklanan insan hareketliliği; kültür, dil, yetenek, din, deneyim ve eğitim gibi farklı değişkenleri içerisinde barındıran karmaşık toplulukların oluşmasına neden olmuştur. Bu çeşitliliğin bir sonucu olarak başta ortak yaşam alanları olmak üzere insanların kullandığı tüm mekânların ve nesnelerin tasarımlarının, toplumdaki her bireyin ihtiyaçlarını karşılayabilmesi daha da önem kazanmıştır (Şenel, Şenel ve Günaydın, 2010). Her türden insanın yaşadığı toplumda rahat ve engelsiz bir yaşam sürmek adına fiziksel çevrenin de tüm ihtiyaçları karşılayabilecek özelliklerde tasarlanması gerekmektedir. Bu nedenle fiziksel çevrenin toplumda yer alan farklı özelliklerdeki her insanın beklenti ve gereksinimlerini karşılayabilecek ve her kitleye erişebilecek nitelikte olmalıdır.

Tasarımcılar, kullanıcı olarak genelde "ortalama insan" kavramını dikkate alma eğilimindedirler. Fakat insanlar; antropolojik ölçüleri, hareket kapasiteleri, kültürel ve sosyolojik özellikleri, fiziksel dayanıklılıkları, görsel, işitsel ve zihinsel yetenekleri bakımından farklılık göstermektedir (Kavak, 2010). Bu nedenle tasarımın tüm kullanıcıların gereksinimlere cevap verebilmesi için tasarımda hedef kitle olarak "herkes" kavramı ele alınmalıdır.

Günümüzde sürekli gelişen ve değişen sosyal, ekonomik ve teknolojik koşullar ve yaşam biçimleri ile beraber insanların kullandığı en küçük ölçekten en büyük ölçeğe her türlü fiziksel çevrede 'erişilebilirlik, ulaşılabilirlik' kavramları ön plana çıkmıştır. Her değişim beraberinde yeni sorunlar gündeme getirmiştir ve insanların daha uzun süre, daha bağımsız ve daha konforlu yaşamaya ihtiyaç duymaları; toplu kullanılan mekânların tasarım anlayışının yeniden ele alınmasını zorunlu kılmıştır (Kavak, 2010). Bu yapılarda ergonomik, işlevsel ve psikolojik konforun sağlanması içerisinde bulunan her türlü fiziksel çevrenin tüm kullanıcıların gereksinimlerini karşılayabilecek şekilde tasarlanması ile mümkündür. Bu noktada herkes için tasarım anlayışını ortaya çıkmıştır. Geçmişten günümüze daha kullanılabilir, erişilebilir ve sürdürülebilir mekânlar yaratmayı ilke edinen bu anlayış hedef olarak herkese ulaşmaya odaklanan bir yaklaşımdır. Bu anlayış özelikle ortak kullanılan toplumsal mekânlar için oldukça önem arz etmektedir.

Bir mekânın kolaylıkla erişilebilir ve kullanılabilir olması için kullanıcıların mekânı deneyimlerken zorlanmamadan konfor ve güven içinde davranışlarını sürdürebilmelerine olanak tanıması gerekmektedir. Ancak çok fonksiyonlu bina tasarımlarında, işlevsel karmaşıklık nedeniyle bu faktörleri sağlamak zorlaşmaktadır (Hojjati, 2019). Toplumdaki her kesim insanın kullandığı eğitim yapıları, sağlık yapıları gibi kamusal yapılar içerisinde birçok işlevi barındıran karmaşık yapılardır. Bu mekânlar ayrıca iletişim kurma, sosyalleşme ve toplum olma bilincinin gelişmesi gibi konularda da önemli rolleri üstlenmektedir. Geçmişten günümüze kadar var olan mekân-insan ilişkisi son yıllarda özellikle kamusal mekânlar için daha odaklanılan bir konu haline gelmiştir (Altay Öztürk, 2019). Farklılıkları gözetmeksizin toplumun her kesimden çeşitli kullanıcı kitlesine sahip olan kamusal mekânlar; toplumsal yaşamda kişilerin hem sosyal hem fiziksel gereksinimlerini karşıladıkları bir alan olarak özel öneme sahiptir (Kavak, 2010).

Kütüphaneler çok sayıda ve çeşitli özelliklerde kullanıcıya kitlesine hitap eden karmaşık fonksiyonlu yapılardır. Kütüphanelerdeki bu yapısal karmaşıklığa rağmen, tasarımcının kullanıcı gruplarının tümünü göz önünde bulundurarak tasarım yapılmalıdır (Hojjati, 2019). Kullanıcısının gereksinimlerinin tümüne cevap vermek ve içerisinde barındırdığı fonksiyonlara rahatlıkla erişebilmek adına evrensel bir yaklaşımla tasarlanmalıdır. Çalışma kapsamında kütüphane yapılarında kullanım verimini arttırarak kaliteli mekânlar oluşturmak adına; çağdaş bir tasarım yaklaşımı olarak evrensel tasarım felsefesinin kütüphane yapıları ile ilişkisini ortaya konarak ve bu veriler ışığında KTÜ Faik Ahmet Barutçu Kütüphanesi irdelenecektir. Bu doğrultuda Faik Ahmet Barutçu örneklemi üzerinden evrensel tasarım ilkeleri kapsamında ortaya konulan eksikliklerin yeni tasarlanan kütüphaneler için kullanılabilirlik ve ulaşılabilirlik açısından önemi vurgulanarak öneriler sunulacaktır.

\subsection{Evrensel Tasarım Yaklaşımı}

Evrensel tasarım, tüm ürün, yapı ve çevrelerin hiçbir fiziksel farklıık gözetmeksizin herkes tarafından ulaşılabilmesine ve kullanılabilmesine imkân sağlayan bütünsel bir tasarım yaklaşımıdır. En küçük ölçekten en büyük ölçeğe kadar her alanı kapsayan bu yaklaşım kullanıcıların yeteneklerine 
bakmaksızın bütün insanların kolaylıkla faydalandığı ve her nesnenin kullanıcının ergonomik özelliklerine uygunluğunu temel alır (Erkovan, 2013).

Evrensel tasarımda temel amaç, ulaşılabilir olma özelliğinin yanında mümkün olabildiği kadar büyük bir kitle tarafından kullanılabilecek ürünler, yapılar ve çevrelerin tasarlanması ve tüm kullanıcılara benzer deneyimler yaşatma hedefiyle insanların mekâna uymasını değil, mekânın insanlara uymasını sağlamaktır (Erkovan, 2013; Şenel, Şenel ve Günaydın, 2018; Dikel, 2019). Bu noktada tasarımcının görevi ise farklı kullanıcıların ihtiyaçlarını göz önünde bulundurarak mekân verimliliğini arttırmayı ve kullanıcıların mekânı kolay ve güvenilir bir şekilde kullanabilmelerini sağlayabilmek amacıyla kullanıcı ihtiyaçlarına karşıık veren mekânlar yaratmaktır. Bu doğrultuda evrensel tasarımda, iç mekân tasarımının ulaşılabilirliği için temel bilgiler ve tasarımlarda uygulanması gereken standartlar bulunmakta ve bu süreçte tasarımcıların ilgili standartlara uyması beklenmektedir.

Evrensel tasarım dünyanın çeşitli yerlerinde "engelsiz tasarım, ulaşılabilir tasarım, herkes için tasarım, kapsayıcı tasarım, kullanıcı odaklı tasarım, gerçek yaşam için tasarım, ömür boyu süren tasarım, kuşaklararası tasarım" gibi kelime grupları ile de ifade edildiği görülse de hedefler genellikle "bağımsızlık, eşitlikçilik, bütünleyicilik, kapsayıcılık, kültürel uyumluluk, sürdürülebilirlik, konfor, güven ve maddi ulaşılabilirlik" gibi amaçlar etrafında şekillenmektedir (Dikel, 2019).

\subsection{Evrensel Tasarım İlkeleri ve Kütüphaneler}

"1989 yılında Ronald L. Mace tarafından temelleri atılan ve 1996 yılında North Carolina State Üniversitesi'nde Evrensel Tasarım Merkezi (The Center for Universal Design) ismini alan merkez, 1997 yılında evrensel tasarım kavramını anlaşılır kılmak ve yol gösterici olmak amacıyla 7 ilke yayımlamıştır" (Altay Öztürk, 2019). Bunlar; eşitlikçi kullanım ilkesi, kullanımda esneklik ilkesi, basit ve sezgisel kullanım ilkesi, algılanabilir bilgi ilkesi, hataya tolerans ilkesi, düşük fiziksel çaba ilkesi ve o yaklaşma ve kullanım için uygun boyut mekân ilkesi olmak üzere yedi ana başlıkta incelenmektedir. Bu ilkeler tüm tasarımcılar için bir rehber niteliği taşımaktadır. Çalışmanın bu bölümünde evrensel tasarım ilkeleri ve bu ilkelerin kütüphane yapıları ile ilişkisi açıklanmıştır. Bu kapsamda Evrensel tasarım ilkeleri, Uluslararası Kütüphane Dernekleri ve Kurumları Federasyonu (IFLA) bildirgelerinde kütüphane tasarımlarına yönelik ibareler doğrultusunda irdelenmiştir.

\subsubsection{Eşitlikçi kullanım ilkesi}

Tasarım her kullanıcının ihtiyaçlarını karşılamaya yönelik eşit imkânlar sağlanmalı ve yaşı, genç, engelli gibi farklı nitelikleri olan kullanıcılar için uygun özelliklerde olmalıdır. Kullanıcılar arasında ayrım yapılmadan tüm faktörlerin her gruptan kullanıcıya hitap edebiliyor şekilde tasarlanması gerekmektedir. Herhangi bir kullanıcıyı ayırmaktan kaçınılmalı, mahremiyet, koruma ve güvenlik tüm kullanııılara eşit olarak sağlanmalı, tasarım tüm kullanıcılar için çekici hale getirilmelidir (Olguntürk 2007; Erkovan 2013).

Eşitlikçi kullanım ilkesi her türden kullanııı kitlesi olan kütüphane yapıları için de önemli bir ilkedir. Uluslararası Kütüphane Dernekleri ve Kurumları Federasyonu (IFLA) yayımladığı bildirgelerde kütüphanelerde eşitlikçi kullanım ilkesine yönelik bulunması gerekli özelliklerden bahsetmektedir. Bu kapsamda bir kütüphane; herkesin erişebileceği ve eğitim verilen alanlara yakın bir yerde konumlandırılmalıdır (IFLA, 2002; IFLA, 2004). Kütüphaneler topluluktaki bütün grupların ve kişilerin gereksinimlerine hitap edebilecek çeşitliliğini sağlamayı amaçlamalı (IFLA, 2004), kullanıcı çeşitlilikleri, demografik değişiklikler, kültürel farklılıklar ve iletişim yöntemleri gibi konularda toplumdaki farklılıkların oluşturduğu gereksinimlerin tümüne hitap edebilir nitelikte tasarlanmalı (IFLA, 2004) ve özel gereksinimlerle karşılaşabilecek engelli kütüphane kullanıcılarına yönelik uygun tasarım yapılmalıdır (IFLA, 2002; IFLA, 2004). İki ya da çok katlı kütüphanelerde girişe yakın yerlerde çocuk arabaları ve tekerlekli sandalyelerin kolaylıkla girebileceği rampalar veya asansörler bulunmalıdır (IFLA, 2004). Raflar tekerlekli sandalye kullanan kişilerin erişebileceği yükseklik ve genişlikte olmalıdır (IFLA, 2004). Tabelalar toplumdaki etnik grupların kullandığı dillere de hitap edecek şekilde ve uygun yerlerde konumlandırımalıdır (IFLA, 2004). Güvenlik önlemleri her türden insan düşünülerek alınmalıdır (IFLA, 2004). 


\subsubsection{Kullanımda esneklik ilkesi}

Tasarım, farklı beceri ve tercihi olan bireyler için alternatif kullanım biçimlerine sahip olmalı ve seçme olanağı sağlamalıdır. Tasarımlar farklı şekilde ve hızda algılayan bireylerin kullanmasına olanak sağlamalıdır (Sayar ve Arat, 2017). Ayrıca kullanıcının kişisel yeterliliklerinin farklı özelliklerde olabileceğini düşünülmeli ve bunu tolere edebilecek esneklikte tasarlanmalıdır.

Kullanımda esneklik ilkesi kütüphanenin daha sürdürülebilir olması farklı kullanım seçenekleri sunması adına kütüphane yapıları için de önemli bir ilkedir. Uluslararası Kütüphane Dernekleri ve Kurumları Federasyonu (IFLA) yayımladığı bildirgelerde kullanımda esneklik ilkesi kapsamında bir kütüphane; gelecekte olabilecek değişikler hakkında ve etkinlikler konusunda çeşitlilik sağlamak için esnek bir yapıya sahip olmalıdır (IFLA, 2002). Faaliyet ve çalışma alanı; bireysel ya da takım halinde toplanma ve işlevsel çalışma ortamı için olanaklar sağlanmalıdır (IFLA, 2002). Raflar ayarlanabilir olmalı, kolay taşınabilmesi için kilitlenebilir tekerlekler kullanılmalıdır (IFLA,2004).

\subsubsection{Basit ve sezgisel kullanım ilkesi}

Tasarım, kullanıcının tecrübesine, bilgisine, becerisine, dil yeteneğine veya mevcut konsantrasyon seviyesine bakmaksızın kolay anlaşılabilir olmalıdır (Kavak,2010). Tasarımda basitliği sağlama ve kolay anlaşılabilmesi; gereksiz karmaşıklığı giderme, tutarlı biçimde bilgi sağlama, okur-yazarlık ve yabancı dil becerilerinin seviyelerine göre hareket edilmesi ile mümkündür (Kavak, 2010). Kullanım sürecinde yeterli geribildirimler ve bilgilerin aktarılması gerekmektedir (Mace, 1997; Hacıhasanoğlu, 2003; Dostoğlu, Şahin ve Taneli, 2009).

Basit ve sezgisel kullanım ilkesi kütüphanenin daha işlevsel olması ve kullanımı kolaylaştırması adına kütüphane yapıları için de önemli bir ilkedir. Uluslararası Kütüphane Dernekleri ve Kurumları Federasyonu (IFLA) yayımladığı bildirgelerde basit ve sezgisel kullanım ilkesi kapsamında bir kütüphane; kişilerin ya da grupların, kütüphanenin herhangi bir parçasını kullanmalarını sınırlamayacak özelliklere sahip olmalı (IFLA, 2004), düzenli aralıklarla erişilebilirliği gözden geçirilmeli ve kolay kullanıma engel olmaması sağlanmalı (IFLA, 2004), kütüphane içinde ya da dışında hizmetlerin sağlanmasında bilgi ve iletişim teknolojilerinin avantaj ve kolaylıklarından da yararlanılmalı (IFLA, 2004), tüm kullanıcıları kolayca uygun kaynaklara yönlendirmeli (IFLA, 2004), kullanıcının ulaşım, erişim ve isteklerine en kısa zamanda yanıt almalı (IFLA,2004) ve kullanılan araç ve gereçler ile kütüphanenin kullanımı kolaylaştırılmalıdır (IFLA, 2004).

\subsubsection{Algılanabilir bilgi ilkesi}

Tasarım, çevresel koşullardan ve kullanıı becerilerinden bağımsız olarak kullanıııya gerekli bilgileri doğrudan, etkili ve algılanabilir şekilde iletebilmelidir (Şenel, Şenel ve Günaydın, 2018). Bu amaçla görsel, işitsel, yazııı, sözel ve dokunsal bilgiye yer verilerek bilgi vurgulanmalı ve verilen bilgi ve arkasının kontrast oluşturması sağlanarak bilginin algılanabilirliği arttırılmalıdır (Sayar ve Arat, 2017; Mace, 1997; Hacıhasanoğlu, 2003; Dostoğlu, Şahin ve Taneli, 2009).

Algılanabilir bilgi ilkesi kütüphanede bilgininin kolayca algılanıp anlaşılmasını kolaylaştırması yönüyle kütüphane yapıları için de önemli bir ilkedir. Uluslararası Kütüphane Dernekleri ve Kurumları Federasyonu (IFLA) yayımladığı bildirgelerde algılanabilir bilgi ilkesi kapsamında bir kütüphanede giriş kolaylıkla görülebilen ve algılanabilen yerinde, binanın kullanıcının en fazla gelmesi beklenen tarafında olması gerektiğini belirtmiştir (IFLA, 2004). Ayrıca kütüphanenin dışındaki tabelalar kütüphanenin kolayca erişilebilmesine olanak sağlayacak şekilde konumlanmalı ve tasarlanmalıdır (IFLA, 2004). İç mekânda ise kullanıcılarla iletişim için ilan panoları, bültenler web sitesi gibi çeşitli yollar sağlanmalı (IFLA, 2004), kütüphane içinde ya da dışında hizmetlerin sağlanmasında bilgi ve iletişim teknolojilerinin avantaj ve kolaylıklarından da yararlanılmalı (IFLA, 2004), hizmetler hakkında bütün bilgiler algılanabilir olmalıdır; örneğin büyük punto (IFLA, 2004) gibi kolay algılanabilir yazı stilleri tercih edilmelidir. Tehlike anında yangın söndürücüleri gibi elemanların yerleri ve acil çıkışlar açıkça belirtilmelidir (IFLA, 2004). Bunun dışında tüm bu tabela ve yönlendirme elemanlarının algılanabilmesi adına hem doğal hem yapay aydınlatmanın uygun ve yeterli derecede olması gerekmektedir (IFLA, 2002; IFLA 2004). 


\subsubsection{Hataya tolerans (risk azaltımı) ilkesi}

Tasarım erişilebilirlik sırasında her türlü tehlike, kaza, hata ve istenmeyen eylemlerin olumsuz sonuçlarını en aza indirmelidir (Mace, 1997; Hacıhasanoğlu, 2003; Dostoğlu, Şahin ve Taneli, 2009; Şenel, Şenel ve Günaydın, 2018). Evrensel tasarım tüm kullanıııları tehlike ve kazalara karşı korumalıdır (Kavak, 2010).

Hataya tolerans ilkesi kütüphanede risk oluşturabilecek konuların en aza indirgenebilmesi açısından her yapı için olduğu gibi kütüphane yapıları için de önemli bir ilkedir. Uluslararası Kütüphane Dernekleri ve Kurumları Federasyonu (IFLA) yayımladığı bildirgelerde hataya tolerans ilkesi kapsamında bir kütüphanede; olası bir tehlikeyi ortadan kaldıracak veya azaltacak önlemlerin alınmalı (IFLA, 2011; IFLA, 2004), bariyer kullanımını azaltmaya odaklanmalı (IFLA, 2004), iç ve dış tasarımda basamak kullanımından olabildiğince kaçınılmalı (IFLA, 2004), kütüphanenin en az bir bölümünün dışarıdan gelen gürültüye karşı korunmalı (IFLA, 2002), yıl boyunca olabilecek hava değişimine bağlı olarak çalışma odalarının ve koleksiyonun korunduğu alanların nem, sıcaklık/soğukluk dereceleri uygun hale getirilmeli (IFLA, 2002), duman ve yangın alarmları yerleştirilmeli (IFLA, 2004), güvenlik açısından bir alarm ve kapalı devre televizyon sistemi kurulması konusu üzerinde ciddiyetle durulmalı ve tüm alanlar iyice aydınlatılmalıdır (IFLA, 2011). Binanın iç ve dış dokusu yangına dayanıklı olmalı (IFLA, 2011), koleksiyonlar; su, elektrik ve mekanik tesisata (su boruları, radyatörler, iklimleme donanımı, mutfaklar, laboratuvarlar) güvenli bir uzaklıkta depolanmalı, selden veya gelen gidenden tahrip olma riskini azaltmak için ciltler, yüksekliği zeminden en az $10 \mathrm{~cm}$ olan raflara dizilmelidir. Olanaklıysa, üstünde siperlik olan raf birimleri kullanılmalıdır, çünkü bunlar su, toz ve zararlı ışı̆ın bir kısmının yönünü değiştirir (IFLA, 2011). Ayrıca raf sistemi güvenliği sağlayacak şekilde tasarlanmalı ve hiç bir çıkıntı veya keskin uç bulunmamalıdır (IFLA, 2011).

\subsubsection{Düşük fiziksel güç gereksinimi ilkesi}

Tasarımın kullanımı kolay olmalı; kullanıcı en az fiziksel çaba ile, fazla efora ihtiyaç duymadan, yorgunluğu en aza indirerek ergonomik ve rahat bir şekilde ürün ve mekânı kullanabilmelidir (Şenel, Şenel ve Günaydın, 2018; Kavak, 2010; Arat ve Sayar, 2017). Net bir ifadeyle; üst üste tekrar eden davranışları gerektirmemeli ve kabul edilebilir derecede güç kullanarak çalıştırılabilmelidir. Mekân ve çevre minimum güç harcanacak kolay ve konforlu şekilde ulaşılabilir olmalıdır (Kavak, 2010).

Düşük fiziksel güç gereksinimi ilkesi minimum güçle konforu ve kolay erişimi sağlaması yönüyle içerisinde birçok mekân ve veri bulunduran kütüphane yapıları için önemli bir ilkedir. Uluslararası Kütüphane Dernekleri ve Kurumları Federasyonu (IFLA) yayımladığı bildirgelerde düşük fiziksel güç gereksinimi ilkesi kapsamında bir kütüphane; her kullanıcının gideceği yere kolayca erişebileceği bir ortam sağlamalıdır (IFLA, 2004). Kütüphane düzenli aralıklarla erişilebilirliği gözden geçirilmeli ve kolay kullanıma engel olacak durumlar ortadan kaldırılmalıdır (IFLA, 2004). Kullanıcılar kolayca uygun kaynaklara yönlendirilebilmelidir. (IFLA, 2004). Tabelalar kütüphanedeki birimleri kolaylıkla bulabilecekleri şekilde konumlanmalı ve tasarlanmalı (IFLA, 2004) ve kioskların (konuşan köşelerin) bütün kullanıcıların kütüphane içinde yön bulmalarını kolaylaştıracak şekilde düzenlenmelidir (IFLA, 2004).

\subsubsection{Yaklaşma ve kullanım için uygun boyut mekân ilkesi}

Tasarımda kullanıcının vücut ölçüleri, duruş pozisyonu ve hareketliliği ne olursa olsun, yaklaşma, uzanabilme, elle kullanım ve genel kullanım için uygun boyut ve alan sağlanmış olmalıdır (Kavak, 2010). Tasarımda fiziksel çevrenin ergonomik olmasında vücut ölçüleri üzerinden ele alınan en temel veriler olan antropometrik boyutlar dikkate alınmalıdır (Ertaş, 2012). Ayakta duran veya oturan kullanıcılar için rahatlıkla kullanılabilen, görüş açısı engelsiz mekân ve ürünler tasarlanmalıdır (Mace, 1997; Hacıhasanoğlu, 2003; Dostoğlu, Şahin ve Taneli, 2009).

Yaklaşma ve kullanım için uygun boyut mekân ilkesi ürünün veya mekanın ergonomisinin sağlanabilmesi yönünden kütüphane yapıları için de oldukça önemli bir ilkedir. Uluslararası Kütüphane Dernekleri ve Kurumları Federasyonu (IFLA) yayımladığı bildirgelerde yaklaşma ve kullanım için uygun boyut mekân ilkesi kapsamında bir kütüphane gereksinim duyduğu kat-alan miktarı kütüphanenin işlevi, kaynakların düzeyi, dermenin büyüklüğüne gibi etkenlere uygun olarak 
tasarlanmalıdır (IFLA, 2004). Hem personel hem de kullanıcıları dolaşımını kolaylaştıracak yeterli alan bulunmalıdır (IFLA, 2004). Kütüphane dermesini sunmaya ve depolamaya ve sunmaya yetecek kadar alan olmalıdır (IFLA, 2004). Roman, bilimsel, ciltli ve karton kapaklı kitaplar, gazeteler ve dergiler, basılı olmayan kaynaklar, depo, çalışma ve okuma alanları, bilgisayarla çalışma yerleri, sergi alanları, görevli çalışma alanları ve bir yardım masası için yeterli boyutta yer sağlanmalıdır (IFLA, 2002). Materyaller açık raflarda tutulmalı ve bu raflar kullanıcıların ulaşabileceği yükseklikte olmalıdır (IFLA, 2004).

\section{Materyal ve Yöntem}

Makalede kullanıcı kitlesindeki çeşitlilik ve yapısında birçok fonksiyon barındırması nedeniyle kütüphane yapılarına odaklanılmıştır. Çalışma alanı olarak Faik Ahmet Barutçu Kütüphanesi belirlenmiştir. Kütüphane 1963 yılında üniversite için açılan bir yarışma ile birinciliği kazanan Doğan Tekeli ve Sami Sisa tarafından tasarlanmıştır. Yarışma projesinin tasarım fikirlerine temelde sadık kalınarak jürilerinin eleştiri ve tavsiyeleri doğrultusunda projede bazı değişiklikler yapılmıştır.

Karadeniz Teknik Üniversitesi'nde bulunan ve üniversitesi öğrencileri, akademik ve idari personeli ile üniversite dışı kullanıcılara hizmet veren Faik Ahmet Barutçu Kütüphanesi üniversite kampüsünün merkezinde konumlandırılmıştır (Durukan, Bekar ve Ertaş Beşir, 2020). Ana girişi güney cephesinde (a) yer alan yapının kuzey cephesi (b) ve doğu cephesi (c) deniz manzaralı olup, batı cephesinde (d) de oluşturulan kırıklı yüzeyler ile manzaradan ve güneşışından faydalanılmıştır (Şekil 1).
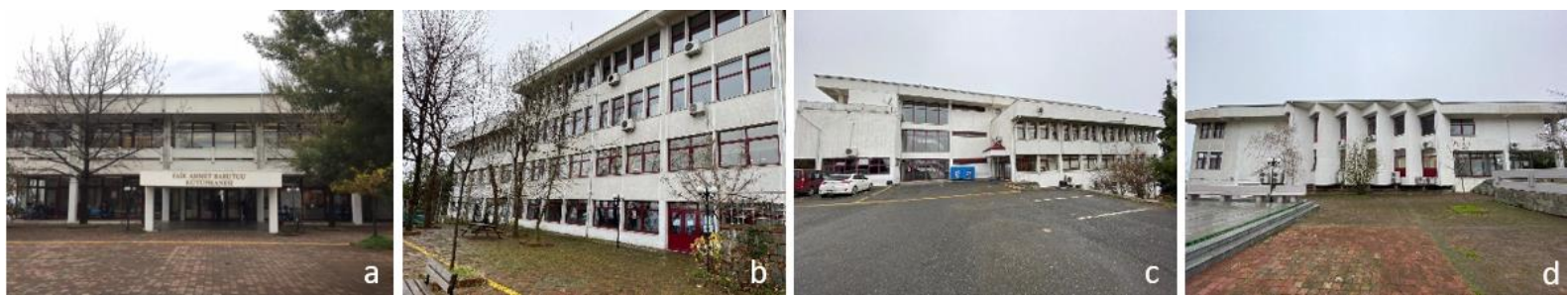

Şekil 1. Faik Ahmet Barutçu Kütüphanesi a. güney cephesi, b. kuzey cephesi, c. doğu cephesi, d. batı cephesi

Kütüphane -2. bodrum kat, -1. bodrum kat, zemin kat ve birinci kat olmak üzere 4 kattan oluşmaktadır (Çizelge 1). Kütüphanenin ana giriş kapısı zemin katta yer almaktadır. Giriş katta; ödünç verme, fotokopi, bilgi tarama ve seminer odası, kitap salonu ve katalog tarama ve lavabolar, birinci katta; ofisler, kitap salonları (tez odası, süreli yayınlar, referans salonu, tarih araştırmaları kitaplığı), çalışma alanları, lavabolar bulunmaktadır. -1. bodrum katta; süreli yayınlar arşivi, cilt atölyesi ve okuma salonu, -2. bodrum katta; serbest çalışma salonu, depo ve teknik oda yer almaktadır (Durukan, Bekar ve Ertaş Beşir, 2020). 
Çizelge 1. KTÜ Faik Ahmet Barutçu Kütüphanesi'ne ait çizimler

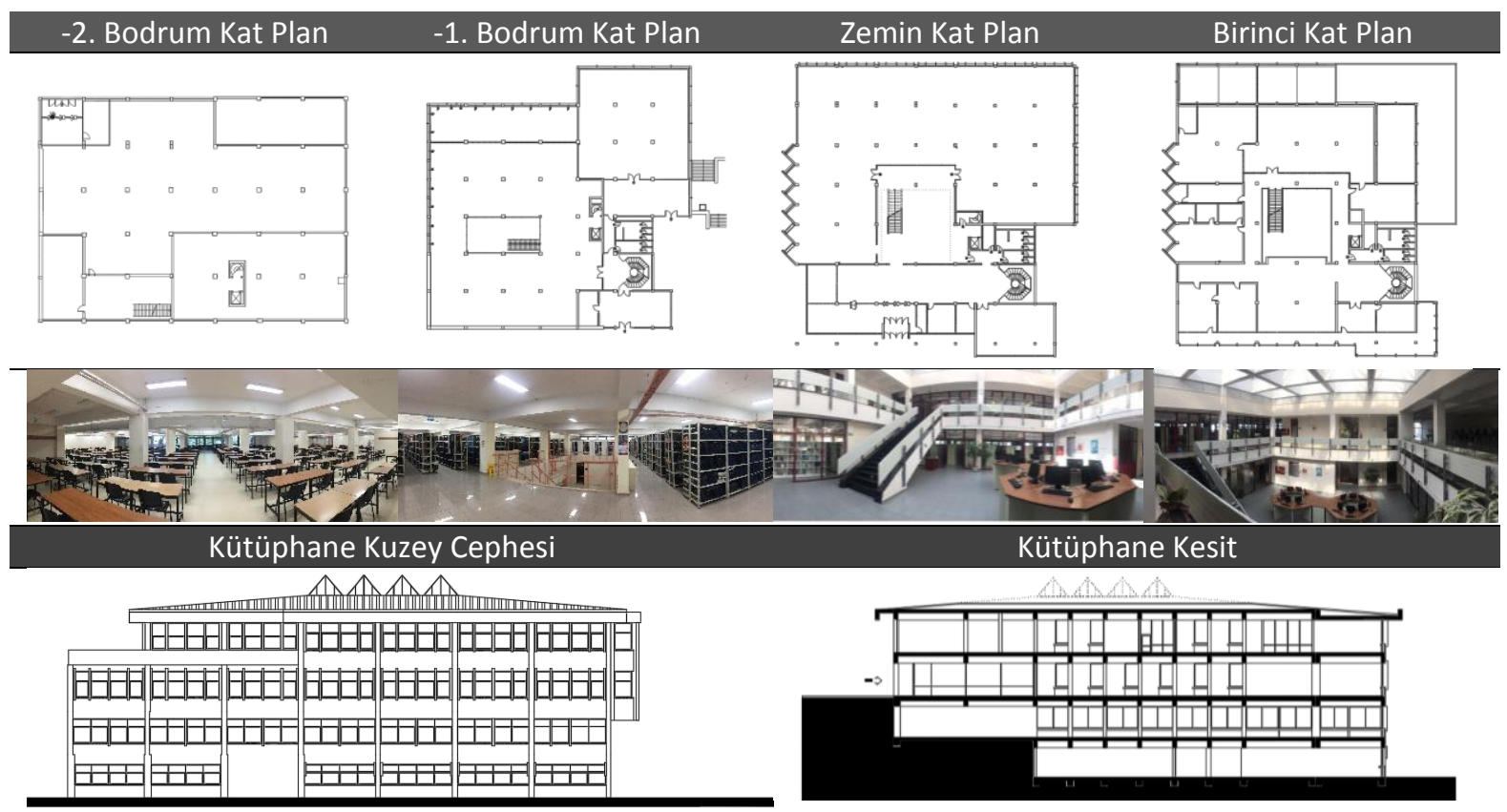

Çalışma konusu doğrultusunda öncelikle evrensel tasarıma ilişkin yerli ve yabancı kaynaklardan literatür tarama çalışması yapılmış ve Uluslararası Kütüphane Dernekleri ve Kurumları Federasyonu tarafından yayımlanan bildirgeler ışığında kütüphanelerde iç mekân tasarımının erişilebilirliğine yönelik veriler ortaya konmuştur. Daha sonra literatür taraması ve IFLA bildirgelerinden elde edilen verilerin evrensel tasarım ilkeleri ile ilişkisi kurularak KTÜ Faik Ahmet Barutçu Kütüphanesi iç mekân tasarımında evrensel tasarım konusu irdelenmiştir. Çalışma sonucunda kütüphane yapılarında kullanım verimini arttırmak ve daha kaliteli mekanlar oluşturmak adına yol gösterecek öneriler sunularak kütüphanelerde evrensel tasarım ilkelerinin önemine dikkat çekmek hedeflenmektedir.

\section{Bulgular ve Tartışma}

Çalışmanın bu bölümünde KTÜ Faik Ahmet Barutçu Kütüphanesi Uluslararası Kütüphane Dernekleri ve Kurumları Federasyonu (IFLA) yayımladığı bildirgeler ışığında ortaya konan kütüphanelerde evrensel tasarım unsurları doğrultusunda incelenmektedir. Bu kapsamda kütüphanede toplu kullanılan mekanlar ele alınmıştır. Bu mekanlar giriş ve çıkış alanları, sirkülasyon alanları, çalışma alanları, kitap salonları ve ıslak hacimlerdir.

\subsection{Giriş ve Çıkış Alanları}

Faik Ahmet Barutçu Kütüphanesi toplam 3 giriş kapısına sahiptir (Çizelge 2). Güney cephesindeki giriş ana giriş olarak kullanılmaktadır. Kuzey cephesi girişi -2. bodrum katta bulunan çalışma alanlarına erişim için kullanılmaktadır. Üçüncü kapı ise batı yönünde bulunup -1. katta bulunan çalışma alanına erişim için kullanılmaktadır.

Çizelge 2. Kütüphanede bulunan giriş ve çıkış alanları

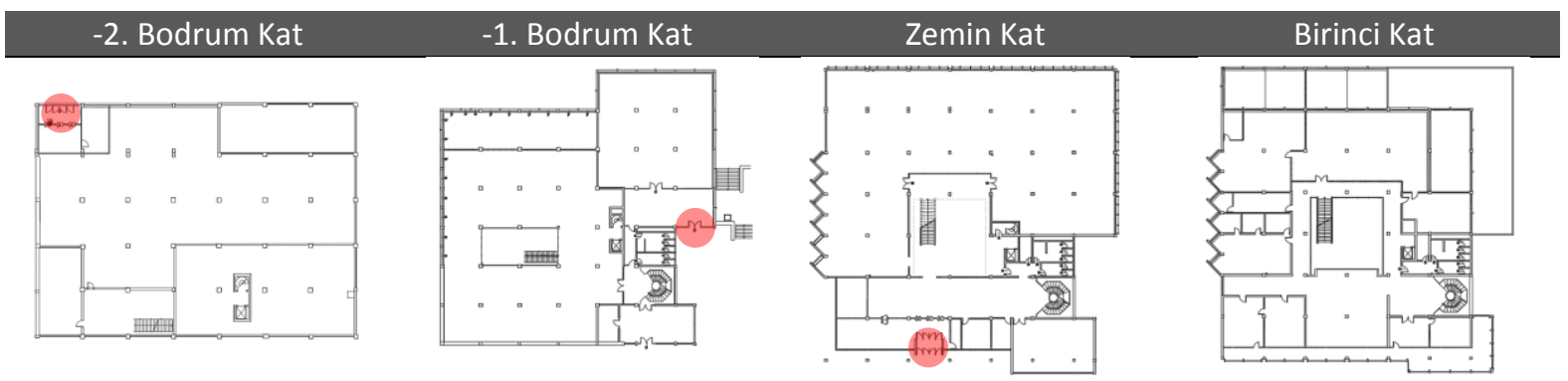

Kütüphanelerde giriş kolaylıkla görülebilen, algılanabilen ve binanın kullanıcının en fazla gelmesi beklenen tarafında olmalıdır (IFLA, 2004). Faik Ahmet Barutçu Kütüphanesi'nin ana giriş kapısı kullanıcıların dışardan ve içerden kolayca erişebileceği şekilde tasarlanmış ve konumlanmıştır. 
Dışarıdaki tabelalar kütüphanenin kolayca erişilebilmesine olanak sağlayacak şekilde konumlanmalı ve tasarlanmalıdır (IFLA, 2004). Kütüphanenin ana giriş kapısı üniversite ana yolundan algılanabilecek bir tasarıma sahiptir ve yol üzerinde bulunan tabela ile beraber kütüphaneye ulaşım kolaylaşmıştır (Şekil 2). Kütüphaneler her kullanııının gereksinimlerine karşılık verebilecek şekilde tasarlanmalıdır (IFLA, 2002; IFLA, 2004). Girişte bulunan küçük bir basamak ve basamakla birlikte konumlandırılmış rampa engelli kullanıcıların da ulaşabilmesine imkân sağlamaktadır. Giriş kapıları her türden kullanıcıya uygun genişlik ve yüksekliktedir. Giriş kapısı manuel olarak açııı kapanmaktadır.
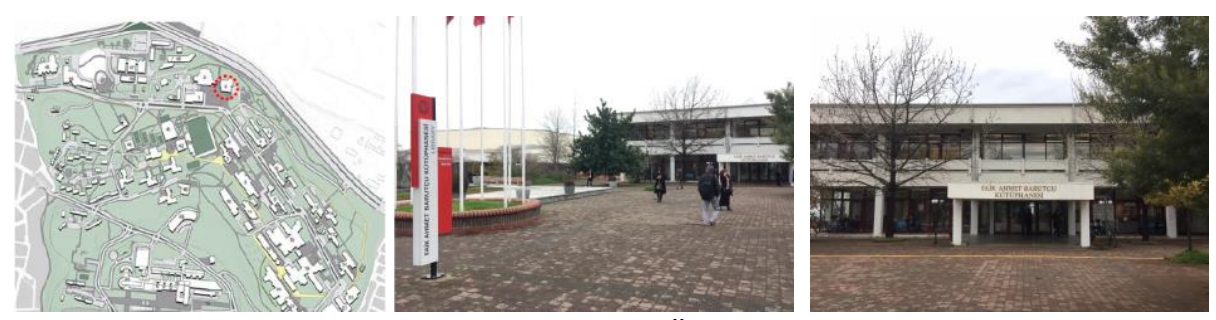

Şekil 2. Kütüphanenin konumu (KTÜ, 2019) ve ana giriş kapıSı

Kütüphaneler olası bir tehlikeyi ortadan kaldıracak veya azaltacak önlemlerin alınmalı gerekmektedir (IFLA, 2011; IFLA, 2004). Faik Ahmet Barutçu Kütüphanesi'nin ana girişinden sonra iç mekâna geçişi sağlayan bir bölüm bulunmaktadır. Burada güvenliği sağlamak amacıyla bir güvenlik birimi, kullanıcı giriş çıkışını kontrol amacıyla kartlı geçiş elemanları ve X-Ray sistemi kullanılmaktadır. Böylece güvenlik ve risk azaltımına yönelik önlemler alınmıştır. Aynı bölmede ayrıca tekerlekli sandalyeli kullanıcılar için geçebileceği daha geniş bir geçiş kapısı yer almaktadır (Şekil 3).
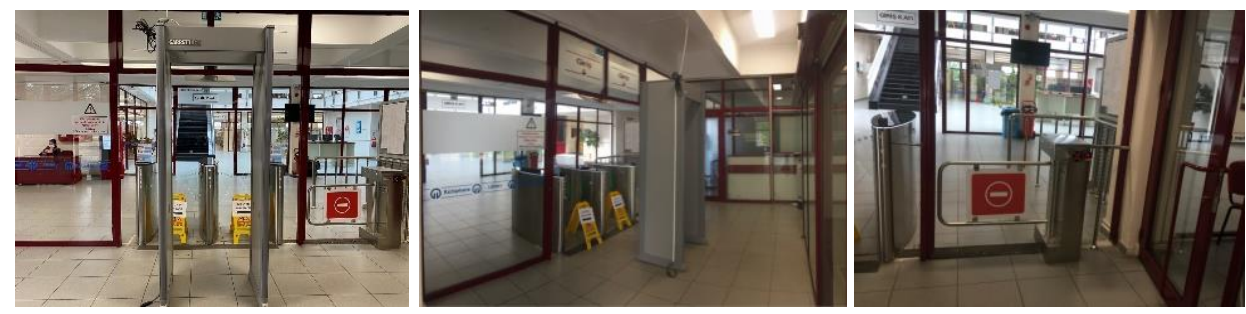

Şekil 3. Kütüphane girişinde yer alan güvenlik önlemleri ve engelliler için geçiş alanı

Kütüphanelerde bulunan her türlü yer yön ve tehlike durumu bildiren elemanlar algılanabilir bilgi ilkesi kapsamında açık ve anlaşılabilir olmalıdır (IFLA, 2004). Faik Ahmet Barutçu Kütüphanesi giriş ve çıkış alanlarında bulunan ve giriş çıkışların yerine gösteren görsel ve yazılı ışıklandırma ile vurgulanmış uyarıcı levhalar bulunmaktadır. Bu levhalar kütüphanenin her katında uygun konumlarda sıklıkla kullanılmıştır (Şekil 4).
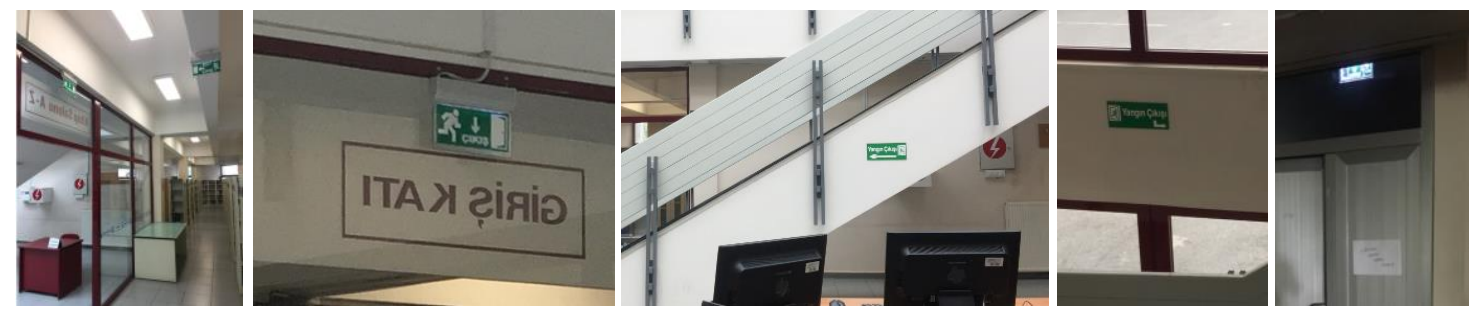

Şekil 4. Kütüphaneden çıkış ve acil çıkışları gösteren tabelalar

Kütüphane giriş çıkış alanları evrensel tasarım kriterleri kapsamında incelendiğinde gerekli düzenlemeleri yapıldığı görülmektedir. Giriş ve çıkışların kolaylıkla ayırt edilebilmesi ve yazılı ve görsel araçlarla desteklenmesi algılanabilirlik ilkesinin dikkate alındığını göstermektedir. Kütüphane girişi güvenlik önlemlerinin alınıp kontrollü giriş çıkışın sağlanarak risk azaltımı ilkesine uyum sağlamaktadır. Ayrıca engelli kullanıcıların girişleri çıkışları dikkate alınmıştır; fakat manuel olarak açılıp kapanan ana giriş kapısı el ve kollarını kullanamayan kullanıcılar için olumsuz bir durum olup eşitlikçi kullanım ilkesi ile örtüşmemektedir. Kütüphane girişinin ölçüleri göz önünde bulundurulduğunda kullanım için uygun boyut mekân ilkesinin bulunduğunu söylemek mümkündür. 


\subsection{Sirkülasyon Alanları}

Faik Ahmet Barutçu kütüphanesinde sirkülasyon düşeyde merdivenler ve asansör, yatayda ise koridorlar aracılığı ile sağlanmaktadır (Çizelge 3).

Çizelge 3. Kütüphanede bulunan temel sirkülasyon alanları

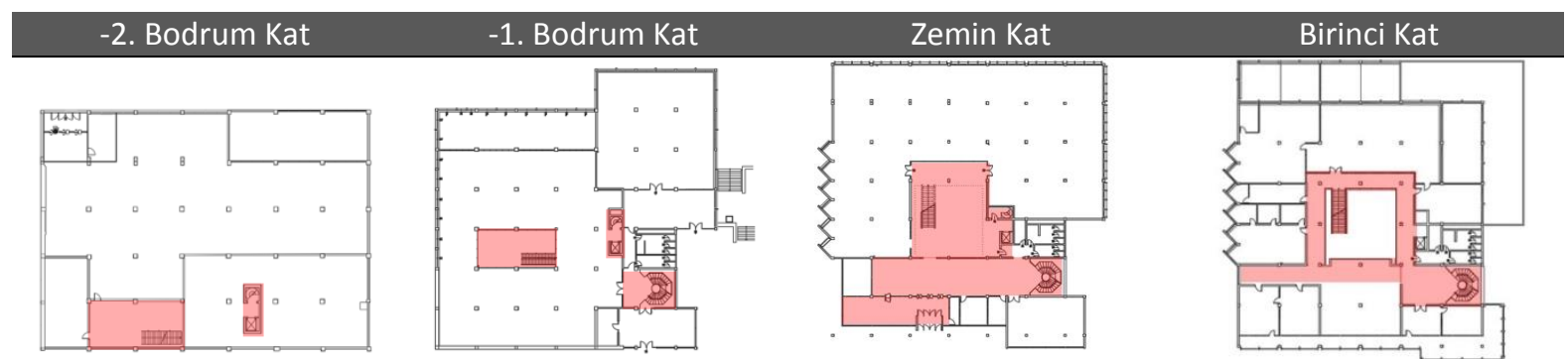

Kütüphanede katlar arası sirkülasyonu sağlayan merdivenler farklı merdiven kurguları bulunmaktadır. Bunlar; kütüphanenin merkezinde bulunan ve kullanıcıların geneline yönelik olan merdiven, çoğunlukla kütüphane personelinin kullandığı ve daha çok ofislerle ilişkisi bulunan döner merdiven, çatıya çıkış için kullanılan merdivendir. Dikey sirkülasyonu sağlayan bir diğer eleman ise asansördür. Asansör kütüphanede tüm katlar arası erişimi sağlayabilmektedir (Şekil 5).
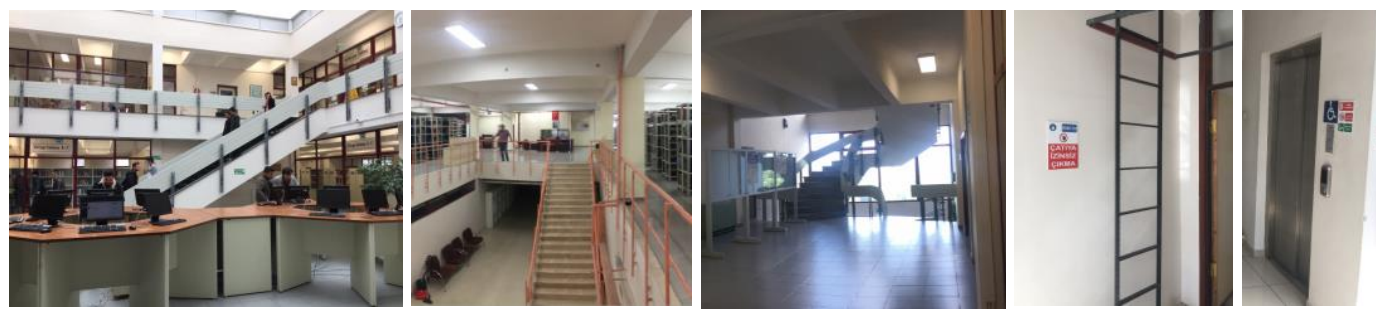

Şekil 5. Kütüphanede bulunan dikey sirkülasyon elemanları

Kütüphanede bulunan merdivenlerin genişliği hem iniş hem de çıkışa imkân verecek ölçülerdedir. Kütüphanelerde olası tehlikeleri ortadan kaldırabilecek önlemlerin alınması gerekliliği (IFLA, 2004; IFLA, 2011) doğrultusunda merdivenlerin her iki tarafında da korkuluk kullanılarak güvenlik önlemleri alınmıştır (Şekil 6). Merdivenlerde rıht yükseklikleri ve basamak genişlikleri güvenlik açısından oldukça önemlidir. Kütüphanedeki merdivenlerde bu açıdan bir sorun gözlemlenmemiştir; basamak genişlikleri kullanıma uygun, rıht yükseklikleri ise birbiriyle tutarlıdır. Merdivenlerin üzerlerinde veya basamakların kenarlarında görsel veya dokunsal uyarı işaretleri bulunmaması hem güvenlik hem de algılanabilirlik açısından eksik görülmüştür. Katlar arası erişimde tekerlekli sandalye kullanıcıları için bir rampa bulunmamakta; bu kullanııılar için katlar arası erişim asansör aracılığı ile sağlanmaktadır. Yer yön ve tehlike durumu bildiren elemanlar yapının her yerinde bulunmalı ve algılanabilir olmalı (IFLA, 2004) bilgisi doğrultusunda merdivenlerde acil çıkışlara yönelik tabelalar yer alması güvenlik ve algılanabilirlik açısından olumludur.
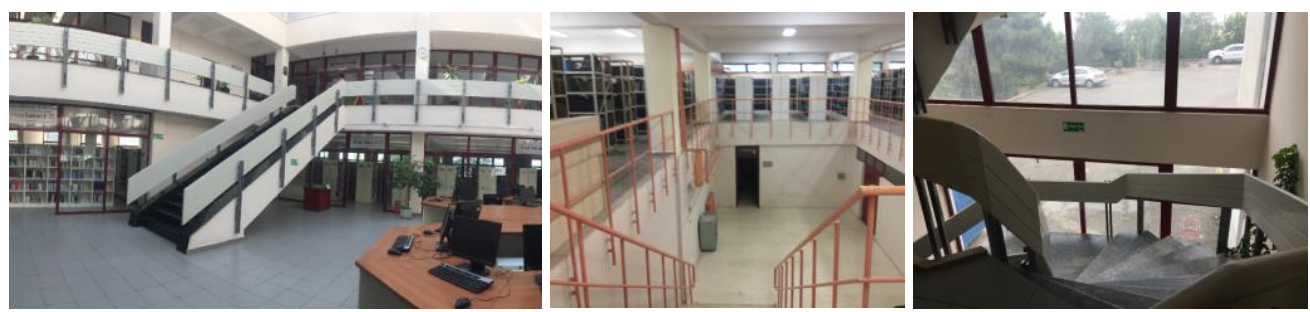

Şekil 6. Kütüphane merdivenler için güvenlik önlemi olarak kullanılan korkuluklar

Kütüphanede katlar arası sirkülasyonu sağlayan bir diğer eleman ise asansördür. Faik Ahmet Barutçu Kütüphanesi'nde bir tane asansör bulunmaktadır. Fakat boyut olarak kütüphanenin kapasitesi için boyutları küçüktür. Genellikle kütüphane personeli veya engelli kullanıcılar tarafından kullanılmaktadır. İki ya da çok katı kütüphanelerde asansörler girişe yakın ve görünür bir yerde (IFLA, 2004) ve tüm kullanıcıları kolayca uygun erişebileceği alanlarda (IFLA, 2004) konumlandırılmalıdır. Fakat Faik Ahmet Barutçu Kütüphanesi'nde bulunan asansör algılanabilirliği zor bir yerde 
konumlandırılmıştır (Şekil 7). Asansörlerin mevcut konumları basit, sezgisel kullanım ve algılanabilirlik açısından olumsuz olarak görülmektedir.

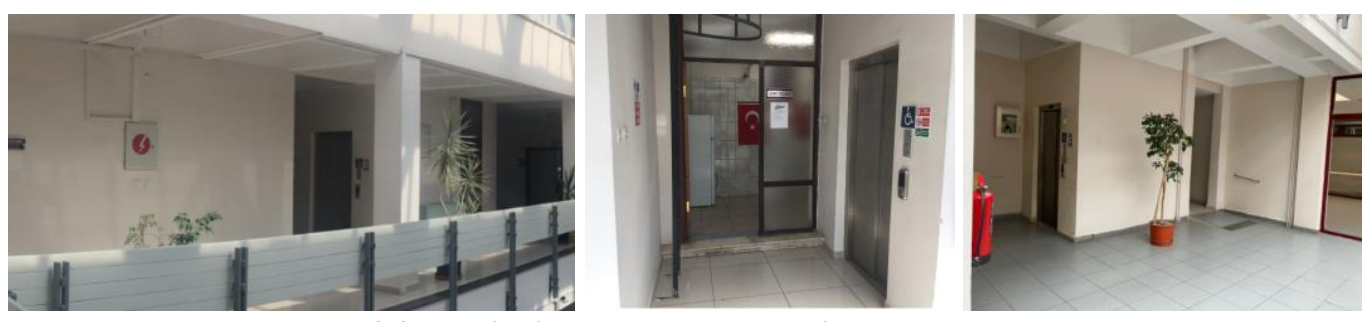

Şekil 7. Faik Ahmet Barutçu Kütüphanesi asansör

Kütüphanede mekânlar arası sirkülasyonu sağlayan bir diğer eleman ise koridorlardır. Kütüphane yapılarında koridorların hem personel hem de kullanıcıları dolaşımını kolaylaştıracak şekilde ve yeterli ölçülerde olması gerekmektedir (IFLA, 2004). Faik Ahmet Barutçu Kütüphanesi'nde bulunan koridorlar oldukça geniş, iki tekerlekli sandalye kullanıcısının rahatlıkla yan yana geçebileceği ve sirkülasyonu engellemeyecek ölçülerde tasarlanmıştır. Ayrıca idari ofisler ve personel ofislerine erişim için kullanılan koridorlarda da hem genişlik hem ulaşılabilirlik açısından uygun olarak tasarlanmıştır. Güvenlik ve risk azaltımı açısından incelendiğinde koridorlarda beklenmedik bir kot değişikliğine rastlanmamaktadır. Fakat birinci katta koridorların ortasında bulunan kolonlar güvenliği azaltan bir unsur olarak görülmüştür (Şekil 8).
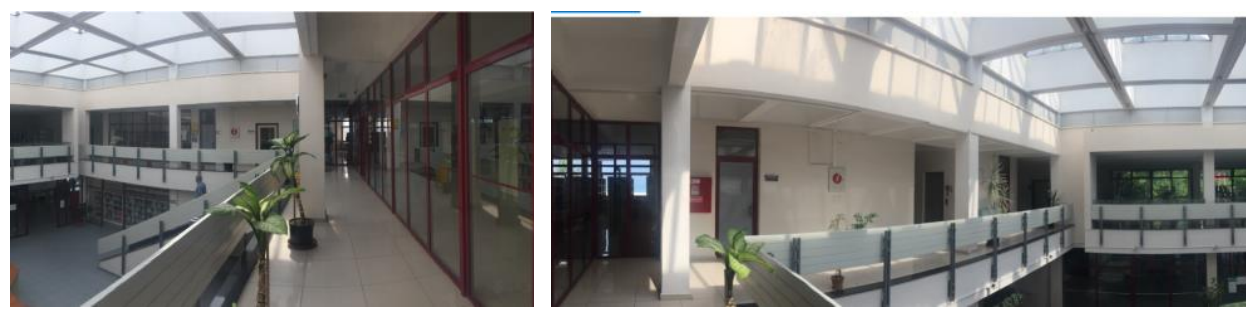

Şekil 8. Kütüphanede güvenliği azaltan kolon kullanımları

Koridorlar yer yön bulma açısından işaretleme ve yönlendirmeye yönelik tabelaların en fazla kullanılması gereken mekânlardır. Bu tabelalar tüm kullanıcıları kolayca hedefe yönlendirmeli (IFLA, 2004), kullanıcının ulaşım, erişim ve isteklerine en kısa zamanda yanıt verebilmeli (IFLA,2004) ve tabelalarda yer alan bilgiler algılanabilir olmalıdır (IFLA, 2004). Faik Ahmet Barutçu Kütüphanesi'nde mekânlar arası erişimde önemli bir yeri bulunan koridorlarda her mekânı tanımlayan işaret ve yönlendirme tabelaları bulunmaktadır (Şekil 9). Bu levhalar mekânın kapıları açık olduğunda dahi algılanabilmesi açısında kapıların yan taraflarına konumlandııılmıştır. Kütüphanelerde bilgi ve iletişim teknolojilerinin avantaj ve kolaylıklarından da yararlanılması (IFLA, 2004) gereksinimi doğrultusunda kaynaklara daha kolay erişebilmek adına otomatik ödünç alma-verme cihazı (selfcheck) yerleştirilmiştir (Şekil 10).

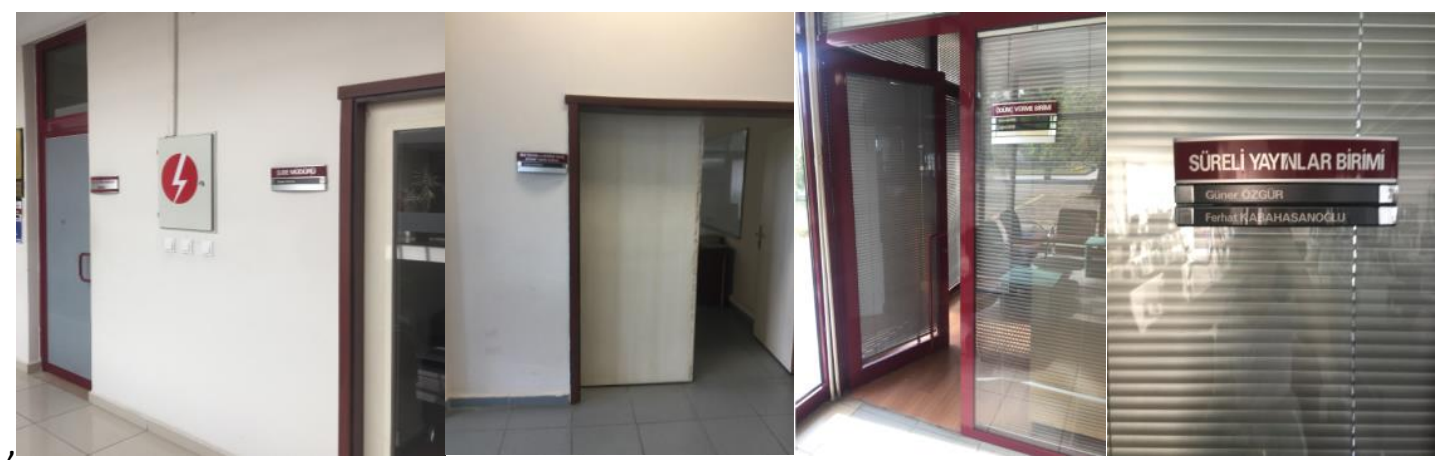

Şekil 9. Koridorlarda bulunan mekân tanımlayan tabelalar 


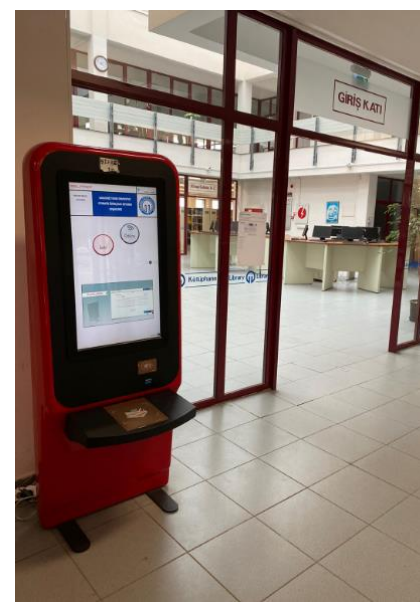

Şekil 10. Selfcheck-in cihazı

Kütüphanede bulunan sirkülasyon sağlama araçları katlar ve mekanlar arası erişimi sağlama, kullanışlılık, eşit kullanım açısından genel olarak yeterli olarak görülmektedir. Fakat dikey sirkülasyon araçlarından asansör konumu basit ve sezgisel kullanım ilkesi ile örtüşmemektedir. Asansörün boyutları kütüphanenin kapasitesine kıyasla küçük kaldığından uygun boyut mekân ilkesi ile uyum sağlamamaktadır. Geniş koridorlar esnek kullanım alanları yaratmıştır. Tüm sirkülasyon elemanları kullanıcının rahatlıkla ulaşmak istediği yere erişimine olanak sağlaması yönüyle düşük fiziksel çaba ilkesi ile örtüşmektedir. Sirkülasyon alanlarında bulunan yangın söndürme cihazları hataya tolerans ve risk azaltımı ilkesi açısından olumlu olarak görülmekte fakat birinci katta koridorların ortasında bulunan kolonlar bu ilke ile örtüşmemektedir.

\section{3. Çalışma Alanları}

Faik Ahmet Barutçu Kütüphanesi'nde çalışma alanları kütüphanenin her katında çeşitli alanlarda bulunmaktadır. -2. bodrum katta serbest çalışma salonu olarak kullanılmaktadır. -1 . bodrum katta girişi doğu cephesinden sağlanan başka bir çalışma alanı yer almaktadır. Zemin katta kitap salonunun pencere önündeki bölümünde masalar ve sandalyeler bulunmakta ve çalışma alanı olarak kullanılmaktadır. Ayrıca birinci katın farklı bölümlerinde de çalışma alanları bulunmaktadır (Çizelge 4)

Çizelge 4. Kütüphanede bulunan çalışma alanları

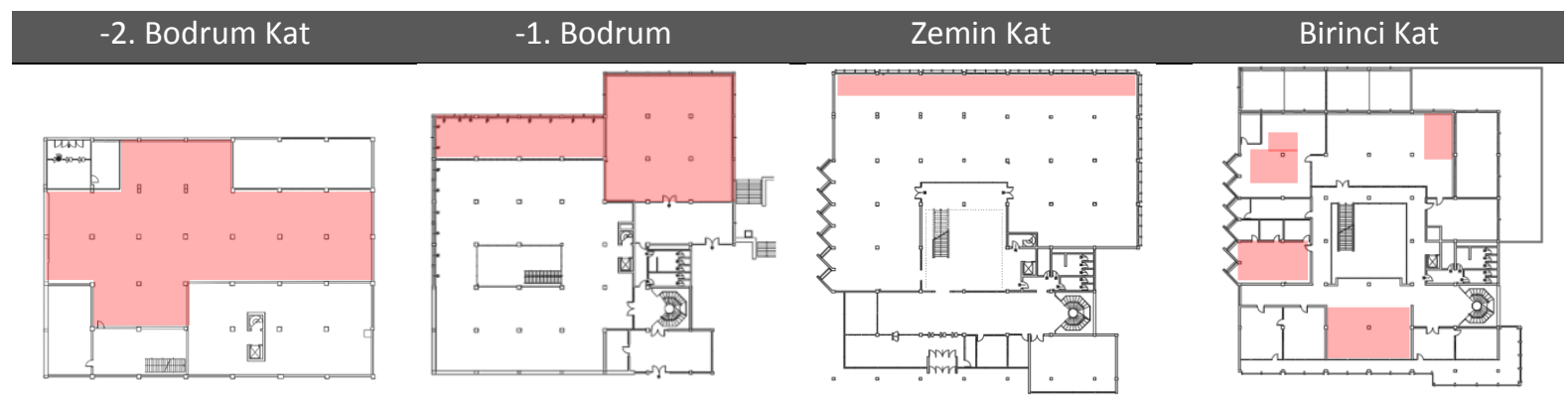

Kütüphanede -2. bodrum katta bulunan geniş alan tamamen serbest çalışma odası olarak kullanılmaktadır. Bu alana giriş kütüphanenin içinden sağlanabilmekte fakat genellikle kuzey cephesindeki giriş tercih edilmektedir. Mekânın kuzey girişinde kontrollü geçişi sağlamak amacıyla kartlı geçiş sistemi kullanılmaktadır. Kütüphanelerde ortak kullanılan tüm mekânlar engelli kütüphane kullanıcılarına yönelik uygun tasarım yapılmalıdır (IFLA, 2002; IFLA, 2004). Fakat Faik Ahmet Barutçu Kütüphanesi -2. bodrum kattaki çalışma alanında masalar ve sandalyelerin birbirine uzaklıkları tekerlekli sandalye kullanıcılarının kullanımı için yetersiz kalmıştır. Kütüphaneler gelecekte olabilecek değişiklikler hakkında ve etkinlikler konusunda çeşitlilik sağlamak için esnek bir yapıya sahip olmalıdır (IFLA, 2002). Ayrıca bireysel ya da takım halinde toplanma ve işlevsel çalışma ortamı için olanaklar sağlanmalıdır (IFLA, 2002). Kütüphanenin bu katında bulunan çalışma alanında kullanılan masaların dikdörtgen formları ve boyutları gerektiğinde bireysel veya grup çalışmalarına imkân verecek şekilde düzenlenebilmesi açısından esnek bir kullanıma sahiptir. Fakat kullanılan donatıların genişlik ve yükseklikleri sabit olması farklı fiziksel özellikleri olan insanlar için esnek kullanıma uygun değildir. 
Mekân geniş bir alan olmasına karşın bölücü elemanların kullanılmaması kullanıcının rahatlıkla boş ve uygun masayı görebilmesi açısından olumludur. Mekânda içerisinde çıkış yönünü ifade eden yazılı ve ışıklı tabelalar kullanıımıştır. Bu katta ayrıca bir ıslak hacim bulunmaktadır. Bu da kullanıcıların üst katlara çıkmasına gerek kalmadan tuvalet ve lavabolara ulaşabilmesi açısından olumludur.

Çalışma alanlarında "Aydınlatma açısından uygun çalışma ortamı sağlanırken mümkün olduğu ölçüde gün ışığından faydalanılmalıdır. Bunun mümkün olmadığı durumlarda gün ışığı ve yapay aydınlatma sistemlerinin birlikte, dengeli olarak kullanılması uygulanabilirlik açısından en uygun çözümdür" (İş Sağlığı ve Güvenliği Araştırma ve Geliştirme Enstitüsü Başkanlığı). Bu doğrultuda; mekânın kuzey cephesinin bir bölümünden doğal ışık alması fakat aydınlatmanın daha çok yapay ışık ile sağlanması çalışma alanındaki verim ve motivasyon açısından olumsuz bir durum olarak görülmektedir (Şekil 11).
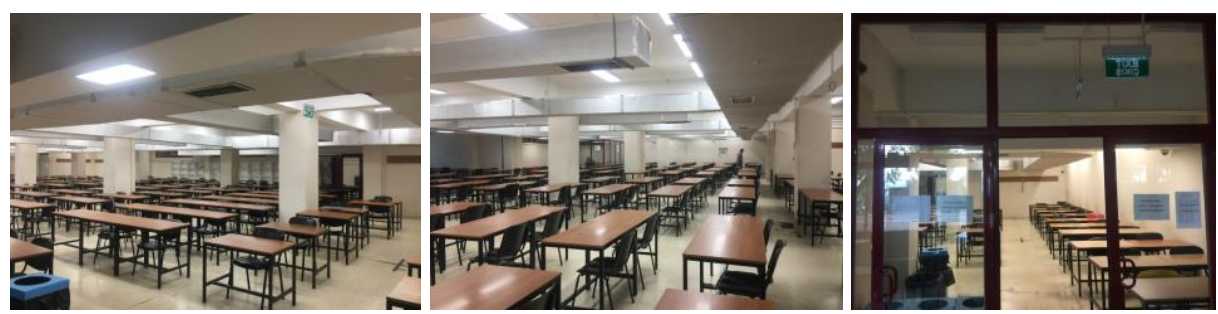

Şekil 11. -2. bodrum kat çalışma alanı

Kütüphanenin -1. bodrum katında bulunan çalışma alanına erişim kütüphanenin dışarısında yan tarafta yer alan merdivenler aracılığı ile doğu cephesindeki girişten sağlanmaktadır. Bu alana kütüphanenin içerisinden de giriş bulunmasına rağmen kullanıcılar doğu cephesindeki dış kapıyı kullanmaya yönlendirilmiştir. Girişte güvenlik önlemleri kapsamında kontrollü geçişi sağlamak amacıyla kartı geçiş sistemleri yer almaktadır. Bu alanın tamamı çalışma salonu olarak kullanılmaktadır. Kullanıcıyı bu çalışma alanına yönlendiren bir eleman bulunmadığından algılanabilirlik açısından yetersiz kalmıştır (Şekil 12).
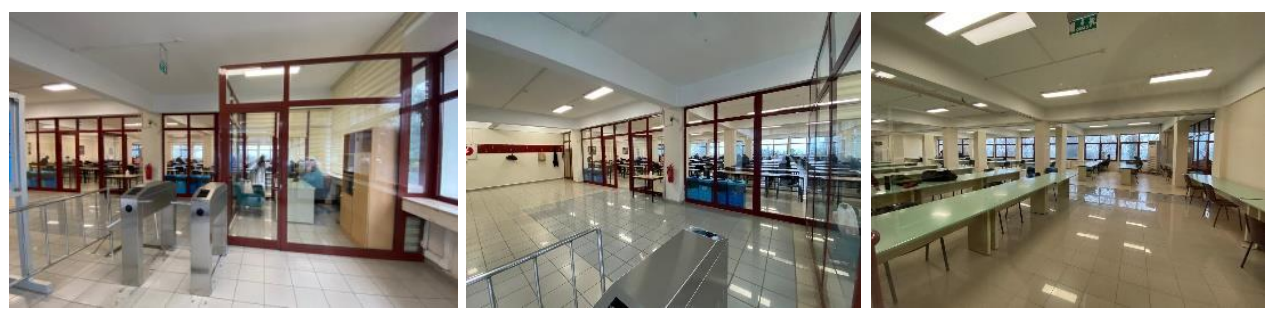

Şekil 12. -1. bodrum katta yer alan çalışma salonu ve girişi

Kütüphanenin zemin kat ve birinci katında bulunan çalışma alanları genellikle kitap salonları ile birlikte çözümlenmiş bölümlerdir. Bu çalışma alanları zemin katta referans salonunun kuzey cephesinde pencerelerin ön kısmında (Şekil 13a), birinci kat süreli yayınlar odasında orta boşlukta (Şekil 13b) ve birinci kat referans salonun sağ köşesinde (Şekil 13c) düzenlenmiş masa ve sandalyeler ile çözümlenmiştir. Birinci katta yer alan tarihi araştırmaları kitaplığı ayrıca engelli çalışma salonu olarak da kullanılmaktadır (Şekil 13d). Ayrıca birinci katta koridor ile birleşik olan düzenlenmiş bir çalışma alanı daha bulunmaktadır (Şekil 13e). Bu alan koridordan herhangi bir bölücü ile ayrılmamıştır. 

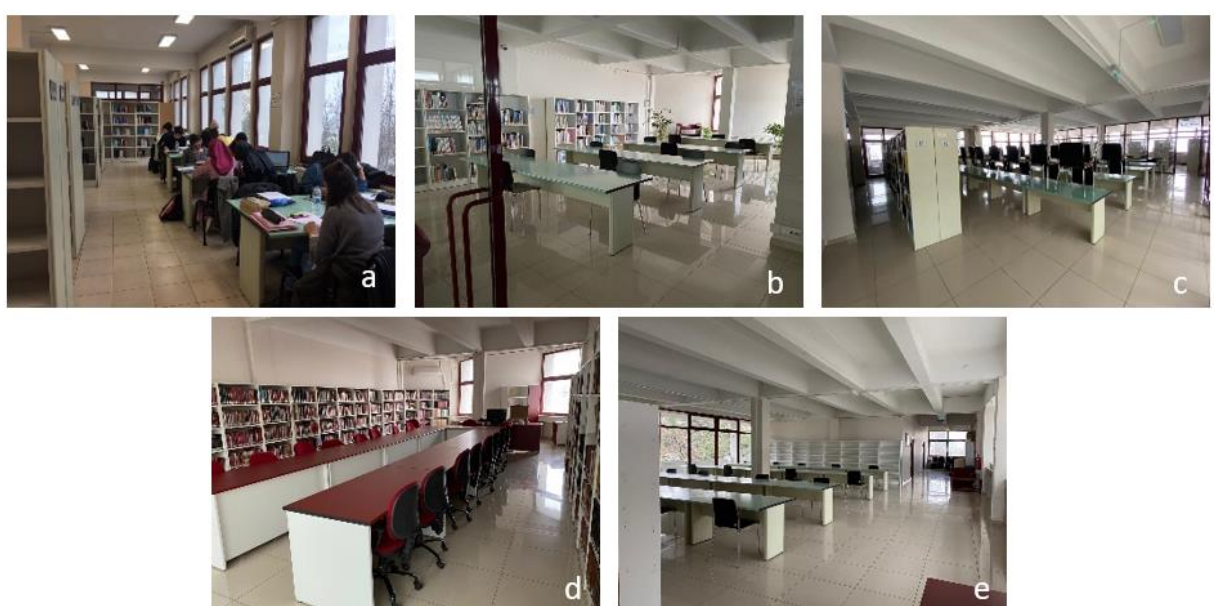

Şekil 13. Zemin kat ve birinci katta yer alan çalışma alanları

Kütüphanedeki çalışma alanları kütüphanenin çeşitli alanlarında bulunmaktadır. Genellikle kitap salonları ile beraber çözülen bu alanlar kullanıcının kaynağa ulaştıktan sonra bulunduğu alanın yakınlarında kaynağı inceleyebilmesi açısından olumlu olarak görülmektedir. Fakat kütüphane kullanıcısının yoğunluğu dikkate alındığında yeteri kadar masanın bulunmadığı gözlemlenmiştir. Uygun masa bulamayan kullanııların kitap salonlarından çıkarak diğer çalışma alanlarına gitmesi düşük fiziksel çaba ilkesi ile örtüşmemektedir. Bu katlarda yer alan çalışma alanlarını tarif eden bir yönlendirme tabelası bulunmaması algılanabilir bilgi ilkesi açısından olumsuz görülmüştür. Dar alanlarda yer alan çalışma alanları (zemin kat) esnek kullanıma engel olmuştur. Pencere kenarında çözümlenen çalışma alanı aydınlatma açısından olumlu gibi görünse de istenmeyen güneş ışığını engelleyecek bir önlem (perde gibi) alınmamıştır. Ayrıca bu alan pencerelerin aniden açılma durumu karşısında güvenlik açısından risk taşımaktadır. Engelliler için çalışma salonu olarak ayrıca bir odanın olması her alanı herkesin kullanabilmesi yani eşitlikçi kullanım ilkesi ile örtüşsmemektedir. Ayrıca bu alanda özellikle tekerlekli sandalye kullananlar için en önde en az bir boşluk bırakılması gerekirken, engelli çalışma salonunda bu uygulanmamıştır. Çalışma alanlarında çıkış yönünü gösteren tabelalar kolaylıkla algılanabilmesi algılanabilir bilgi ilkesi açısından olumlu bir durumdur.

\subsection{Kitap Salonları}

Fail Ahmet Barutçu Kütüphanesi'nde kitap, dergi vb. kaynakların yer aldığı farklı alanlar yer almaktadır. Zemin katta geniş bir referans salonu, birinci katta süreli yayınlar, referans salonu, tez odası ve tarih araştırmaları kitaplığı bulunmaktadır. Ayrıca -1. bodrum katta süreli yayınların yer aldığı bir arşiv bulunmaktadır (Çizelge 5).

Çizelge 5. Kütüphanede bulunan kitap salonları

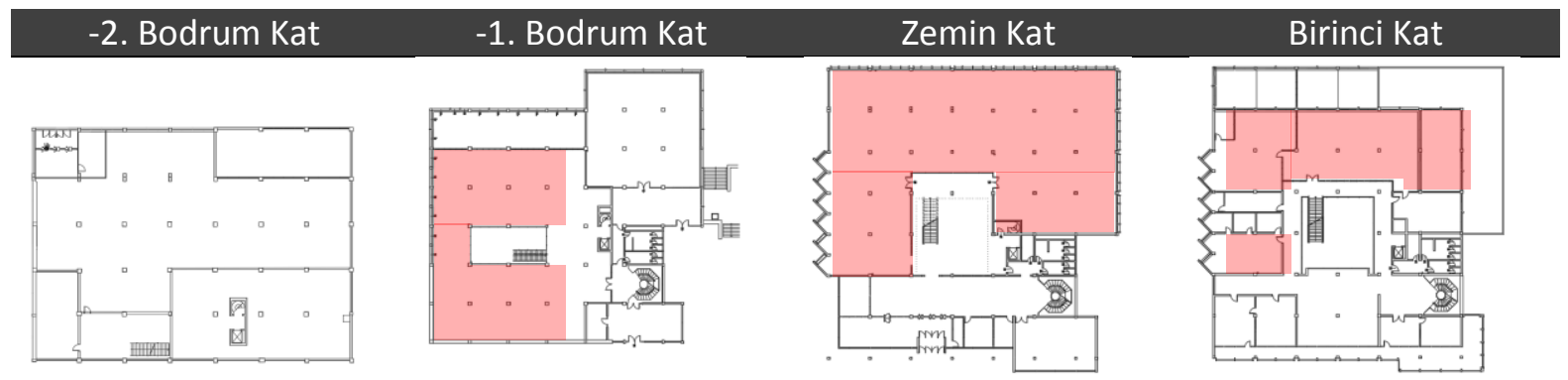

Faik Ahmet Barutçu Kütüphanesi kitap salonları sirkülasyon alanları ile birleşimi bakımından ulaşılabilir olduğu, birçoğunun sirkülasyon alanından cam bölücülerle ayrıldığı, tüm bu birimlerin girişlerinde o alanı eden tabelaların olduğu; böylece algılanabilirliğinin arttığı görülmüştür. Kitap salonları genellikle birbiri ardına birçok dolapların sıralanması ile organize edilmiştir. Kütüphanelerde kullanıcılar kolayca uygun kaynaklara yönlendirilebilmesi için yeterli araç, gereç ve yönlendirme elemanları bulunmalıdır (IFLA, 2004). Bu doğrultuda bakıldığından Faik Ahmet Barutçu Kütüphanesi'ndeki kitaplıkların her birinde o sıradaki kaynakları tarif eden tabelaların bulunması, kitapların kolaylıkla bulunabilmesi için üzerlerine kodların yapıştırılması ve kitaplıkların tümü açık rafı 
dolap sistemleri olarak tasarlanması algılanabilirlik, basit kullanım ve düşük fiziksel çaba ilkeleri bakımından olumlu bir yaklaşım olarak görülmektedir. Kütüphanelerde kullanılan kitaplıklarda raflar ayarlanabilir olmalı, kolay taşınabilmesi için kilitlenebilir tekerlekler kullanılmalıdır (IFLA, 2004). Faik Ahmet Barutçu Kütüphanesi'nde kullanılan kitap dolapların bu özelliklere sahip olmaması dolapların yerin değişmesini ve esnek kullanımını zorlaştırmaktadır. Materyaller açık raflarda tutulmalı ve bu raflar kullanıcıların ulaşabileceği yükseklikte olmalıdır (IFLA, 2004). Bu doğrultuda kütüphanedeki kitap dolaplarının açık rafı olması olumlu bir durum olarak görülürken; rafların özellikle tekerlekli sandalye kullanıcıları için ulaşılabilir olmaması eşitlikçi kullanım açısından olumsuz görülmüştür. Kütüphanelerde mekanların kullanılabilmesi için yeterli boyutta alan sağlanmalıdır (IFLA, 2002). Fakat Faik Ahmet Barutçu Kütüphanesi'nde dolapların arasındaki boşluklar iki kişinin aynı anda geçişi veya kullanımı için yeterli mesafede değildir. Buna ek olarak tekerlekli sandalye kullanıcılarının sirküle edebilmesi veya manevra yapabilmesi için yeterli mesafeler bulunmamaktadır (Şekil 14).

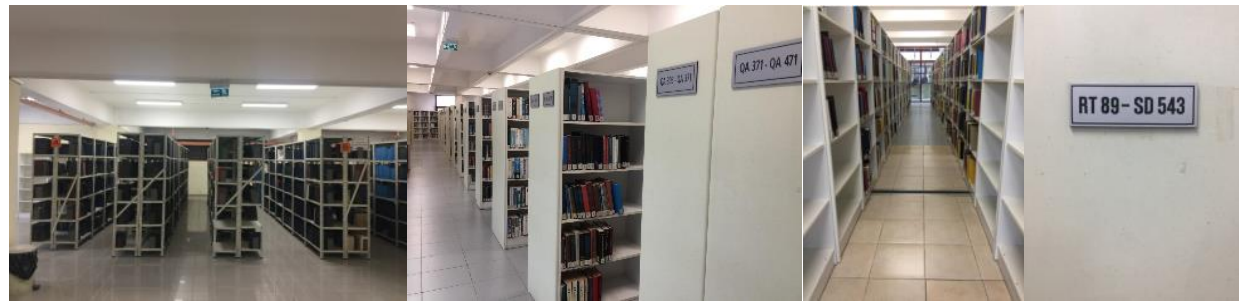

Şekil 14. Kitap salonları

Birinci katta tarih araştırmaları odası ve süreli yayınlar salonu olarak kullanılan bölümlerde diğer kitap salonlarından farklı olarak kitaplıklar duvarlara yaslı bir şekilde organize edilmiştir. Tarih araştırmaları salonu aynı zamanda engelli çalışma salonu olarak da kullanıldığından daha geniş sirkülasyon koridorları oluşturulmuştur. Fakat biri masada otururken arkasından geçecek olan kullanııının geçiş alanı yine de yetersiz kalmaktadır. Kullanılan oturma birimlerinin yüksekliklerinin ayarlanabilir olması farklı boylardaki insanların kullanabilmesine imkân tanımaktadır. Süreli yayınlar birimi ise ortasında çalışma alanını ile birlikte çözümlenmiştir. Geniş bir iç alana sahip olan süreli yayınlar birimi esnek bir yerleşim alanına sahiptir. Kullanılan koltukların genişlik ve yükseklikleri sabit olması farklı fiziksel özellikleri olan insanlar için uygun değildir (Şekil 15).
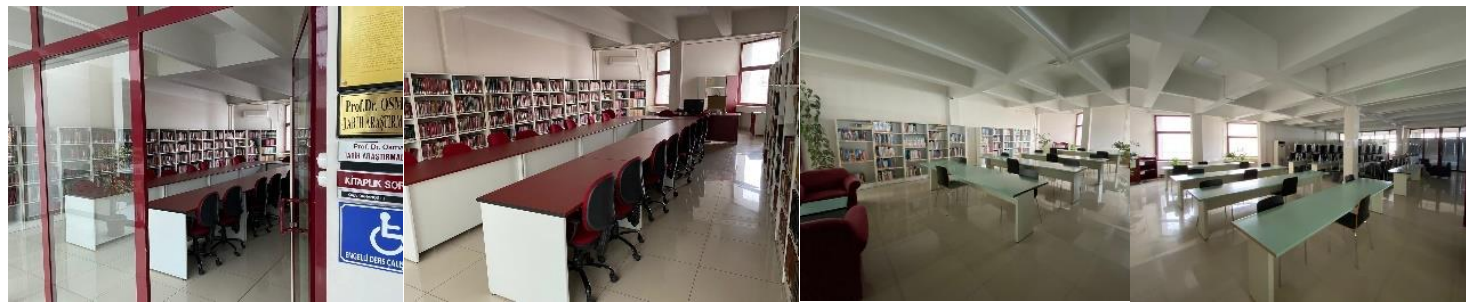

Şekil 15. Tarih araştırmaları kitap salonu ve süreli yayınlar kitap salonu

Kitap salonlarının genelinde engelli kullanıcılara yönelik düzenlemelere rastlanmaması eşitlikçi kullanım ilkesine ters bir tutumdur. Kitap salonları iç mekân yerleşimi, donatıların yoğunluğu ve donatıların hareketli ayaklara sahip olmaması bakımından esneklik ilkesi ile örtüşmemektedir. Ayrıca kitap dolapları arasındaki dar sirkülasyon alanları hem ergonomik kullanım açısından hem de uygun boyut mekân ilkesi açısından yetersizdir.

\subsection{Islak Hacimler}

Islak hacimlerin tasarımı tüm yapılarda olduğu gibi özellikle toplu kullanım mekanlarında önemli konudur. KTÜ Faik Ahmet Barutçu kütüphanesinin her katında ıslak hacimler her katta yer almaktadır. Katlarda yaklaşık olarak aynı hizalarda çözümlenen tuvaletlerin kapasiteleri farklılık göstermektedir. Bazı tuvaletlerde üç kabin bulunurken bazılarında iki kabine rastlanmıştır. Tuvaletlerin tasarım ve organizasyonları genel olarak benzer özellikler taşımaktadır (Çizelge 6). 
Çizelge 6. Kütüphanede bulunan ıslak hacimler
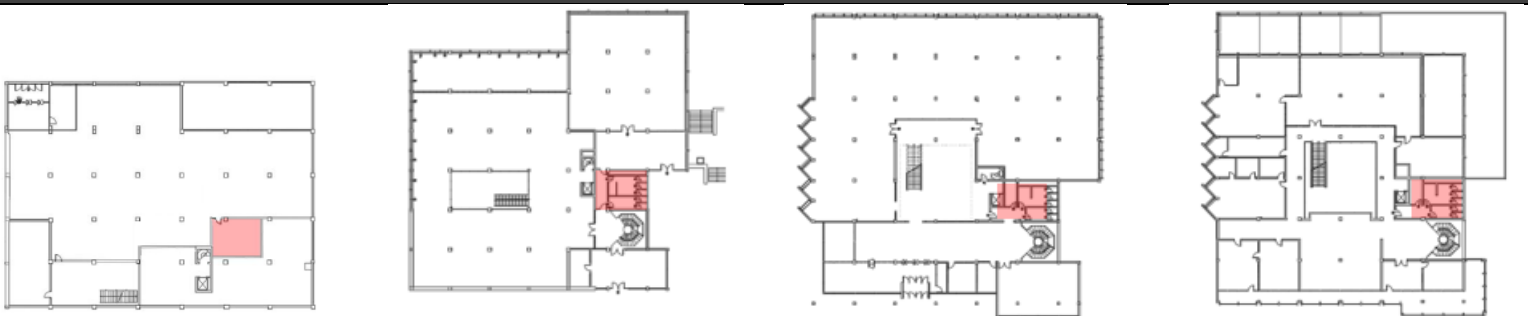

Tuvaletler kullanıcıların kolaylıkla ulaşabileceği yerlerde konumlandırılmıştır. Tuvaletlerde kullanılan her tefrişin erişilebilir olması gerekmektedir. Fakat Faik Ahmet Barutçu Kütüphanesi'nde farklı fiziksel boyutlara sahip kullanıcılara yönelik farklı yüksekliklerde lavaboların olmaması ve aynaların yüksekliklerinin her kullanıcının erişebileceği şekilde konumlandırımaması farklı fiziksel boyutlardaki kullanıcıların erişimlerini karşılayamamaktadır (Şekil 16). Tuvaletlerde kullanıcının çanta, eşya vb. eşyalarını koyabileceği alanlar yaratılmamıştır. Kütüphanede engelliler için tasarlanmış tuvaletler de bulunmaktadır. Engelliler için ayrılmıs tuvaletler diğer tuvaletlerden ayrılmıştır. Engelli tuvaletleri içerisinde bulunması gereken gerekli tefrişlerin mevcut olduğu görülmektedir (Şekil 17).

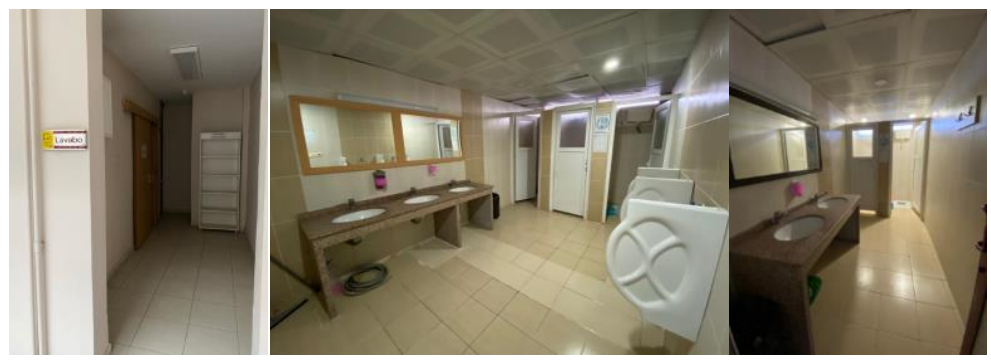

Şekil 16. Kütüphanede bulunan tuvaletler

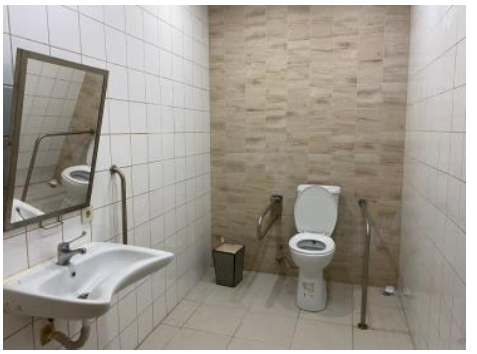

Şekil 17. Engelli tuvaleti

Faik Ahmet Barutçu Kütüphanesi'nde bulunan ıslak hacimlerin genelinde kullanıcı çeşitliliği göz ardı edilerek tek tip tefriş ölçüleri kullanılmıştır. Sirkülasyon alanlarında ve ıslak hacim girişlerinde görsel ve yazılı yönlendirme tabelaların bulunması mekânın algılanabilirliğini desteklemektedir.

\section{Sonuç ve Öneriler}

Kütüphaneler insanların kaynaklara ulaşmak için bir araya geldikleri toplumun faklı kesimlerinden çeşitli özelliklere sahip bireylerin kullandığı ve içerisinde birçok farklı işlevi barındıran toplumsal yapılardır. Bu nedenle kütüphanelerin her türlü kültürel, fizyolojik, ekonomik ve sosyal farklılıklara sahip olan kullanıcılara hitap etmesi gerekmektedir. Çalışmada KTÜ Faik Ahmet Barutçu Kütüphanesi evrensel tasarım ilkeleri bakımından irdelenmiştir. Kütüphanede yapılan araştırma sonucu ortaya konulan eksikliklerin yeni tasarlanan kütüphaneler için kullanılabilirlik ve ulaşılabilirlik açısından bulgular ortaya konulmuştur. Bu kapsamda Faik Ahmet Barutçu Kütüphanesi'nde özellikle eşitlikçi kullanım, algılanabilir bilgi, uygun boyut mekân ilkesi yönünden eksiklikler tespit edilmiş ve bunlara yönelik çözüm öneriler sunulmuştur.

- Kütüphanede bulunan mekânlar çoğunlukla engelli kullanımı göz ardı edilerek tasarlanmıştır. İç mekân örgütlenmeleri engelli kullanııların erişimini sınırlamaktadır. Bu doğrultuda; görme engelliler için sesli yönlendirme elemanları, Braille alfabeli levhalar olmalıdır. Yeterli duyusal 
uyarma olmadığında yön takibinde problemler ortaya çıkacaktır. İşitme engeli olan kullanıcılar için sesli uyarı ve yönlendirme panoları yer almalıdır. Engelli bireyler için uygun bölgelerde alternatif oturma alanları bulunmalıdır. Çalışma alanlarında ve kitap salonlarında tekerlekli sandalye kullanıcıları için rahat sirküle edebilecekleri ve kolaylıkla manevra yapabilecekleri boşluklar yaratılmalıdır.

- Kütüphanede kullanılan donatılar farklı fiziksel boyutlara sahip kullanıcıların ihtiyaçlarını aynı ölçüde karşılayamamaktadır. Bu nedenle donatıların boyutları her kullanıcının fiziksel ölçülerine uygun olacak şekilde tasarlanmalı ya da yükseklikleri ayarlanabilir elemanlar tercih edilmelidir. Ayrıca tüm donatı, araç ve gereçlerin engellilerin de erişebilip kullanabilecekleri şekilde tasarlanmalı ve konumlandırılmalıdır.

- Kütüphanede tüm bilgiler ulaşılabilir, algılanabilir ve kullanımı kolaylaştıracak şekilde sunulmalıdır. Tüm mekânların yerlerini belirtecek yazılı veya görsel yönlendirme elemanları kullanılmalıdır. Görsel ve yazılı bilgi ve yönlendirme elemanları arka fon ile kontrast oluşturacak şekilde seçilmeli veya tasarlanmalıdır.

- Kütüphanede çalışma mekanları daha çok yapay aydınlatmalar yoluyla sağlaması motivasyon ve verimin olumsuz yönde etkilemektedir. Çalışma alanlarında aydınlatma olarak mümkün olduğu ölçüde gün ışığından faydalanmalıdır.

- Sirkülasyon alanlarında engel oluşturacak her türlü nesne ortadan kaldırılmalı; bunun mümkün olmadığı durumlarda uyarı işaretlemeleri yapılmalıdır.

Tüm bunlar dikkate alındığında Faik Ahmet Barutçu Kütüphanesi erişilebilirlik açısından bazı yönlerde yetersiz kaldığı görülmektedir. Kütüphanenin daha verimli, rahat kullanılabilen, motivasyonu yüksek bir alan olabilmesi adına kullanıcıya daha eşit, daha erişilebilir imkânların sunulması gerekmektedir.

\section{Teşekkür ve Bilgi Notu}

Makalede, ulusal ve uluslararası araştırma ve yayın etiğine uyulmuştur. Çalışmada etik kurul izni gerekmemiştir.

\section{Kaynaklar}

Altay Öztürk, M. (2019). Kamusal mekân olarak sağlık bilimleri üniversitesi Antalya eğitim ve araştırma hastanesi genel mekanlarının evrensel tasarım prensipleri ışı̆̆ında incelenmesi (Yüksek lisans tezi). Mimar Sinan Güzel Sanatlar Üniversitesi, Fen Bilimleri Enstitüsü, İ̧ Mimarlık Anabilim Dalı İstanbul. Erişim Adresi (14.01.2021): https://tez.yok.gov.tr/UlusalTezMerkezi/tezSorguSonucYeni.jsp

Dikel, Y. Z. (2019). Evrensel tasarım kapsamında kullanıcıların iç mekân donatılarına erişebilirliğinin incelenmesi (Yüksek lisans tezi). Mimar Sinan Güzel Sanatlar Üniversitesi, Fen Bilimleri Enstitüsü, iç Mimarlık Anabilim Dalı. Erişim Adresi (17.01.2021): https://tez.yok.gov.tr/UlusalTezMerkezi/tezSorguSonucYeni.jsp

Dostoğlu, N., Şahin, E., Taneli, Y. (2009). Tasarıma Kapsayıcı Yaklaşım: Herkes İçin Tasarım Evrensel Tasarım: Tanımlar, Hedefler, Illkeler, Mimarlık Dergisi, 347. Erişim Adresi (10.01.2021): http://www.mimarlikdergisi.com/index.cfm?sayfa=mimarlik\&DergiSayi=361\&ReclD=2062

Durukan, A., Bekar I., Ertaş Beşir, Ş. (2020). KTÜ Faik Ahmet Barutçu Kütüphanesi'nin İşaret ve Yönlendirme Tasarımı Bileşenlerinin Tespiti, The Journal of Academic Social Sciences, 108, 404 $417 . \quad$ Erişim Adresi

(15.01.2021): https://asosjournal.com/index.jsp?mod=makale_tr_ozet\&makale_id=44769

Erkovan, E. (2013). Evrensel tasarım ilkeleri kapsamında bir kamusal alan olarak Akdeniz Üniversitesi Kampüsü'nün incelenmesi (Yüksek lisans tezi). Bahçeşehir Üniversitesi, Fen Bilimleri Enstitüsü, Kentsel Sistemler ve Ulaştırma Yönetimi Anabilim Dalı, İstanbul. Erişim Adresi (14.01.2021): https://tez.yok.gov.tr/UlusalTezMerkezi/tezSorguSonucYeni.jsp 
Ertaş, Ş. (2012). Çocuk ve spor ilişkisi üzerine fiziksel biçimlenmeyi etkileyen ergonomik faktörlere dayalı bir model. Yayımlanmamış Yüksek Lisans Tezi. Karadeniz Teknik Üniversitesi, Fen Bilimleri Enstitüsü, Trabzon.

Hacıhasanoğlu, I. (2003). Evrensel Tasarım. Tasarım Kuram Dergisi, 2 (3), 93-101. Erişim Adresi (12.01.2021): https://www.researchgate.net/publication/317995337_Evrensel_Tasarim

Hojjati, S. A. (2019). Evrensel tasarım çerçevesinde bir inceleme: Trabzon Kaşüstü Kanuni Eğitim ve Araştırma Hastanesi (Yüksek Lisans Tezi). Karadeniz Teknik Üniversitesi, Fen Bilimleri Enstitüsü, Mimarlık Anabilim Dalı, Trabzon. Erişim Adresi (14.01.2021): https://tez.yok.gov.tr/UlusalTezMerkezi/tezSorguSonucYeni.jsp

IFLA, (2002). The International Federation of Library Associations and Institutions. IFLA/UNESCO Okul Kütüphanesi Rehberi. Erişim Adresi (15.12.2019): https://www.ifla.org/files/assets/schoollibraries-resource-centers/publications/school-library-guidelines/school-library-guidelinestr.pdf

IFLA, (2004). The International Federation of Library Associations and Institutions. Halk Kütüphanesi Hizmeti, Gelişim için IFLA/UNESCO ilkeleri. Erişim Adresi (18.12.2019): http://yunus.hacettepe.edu.tr/ byilmaz/byilmaz/iflaunescobildiri.pdf

IFLA, (2011). The International Federation of Library Associations and Institutions. Kütüphane Malzemesinin Bakım ve Kullanımında IFLA ilkeleri. Erişim Adresi (13.12.2019): https://www.ifla.org/files/assets/pac/ipi/ipi1-tr.pdf

Kavak, M. (2010). Evrensel tasarım yaklaşımı bağlamında kamusal mekanlar: Harbiye Kongre Vadisi örneği (Yüksek lisans tezi). Bahçeşehir Üniversitesi, Fen Bilimleri Enstitüsü, Kentsel Sistemler ve Ulaştırma Yönetimi Anabilim Dalı, İstanbul. Erişim Adresi (12.01.2021): https://tez.yok.gov.tr/UlusalTezMerkezi/tezSorguSonucYeni.jsp

KTÜ, (2019). Karadeniz Teknik Üniversitesi Kanuni Yerleşkesi Yapıları ve Mimarları. Erişim Adresi (15.12.2019): http://www.ktu.edu.tr/dosyalar/pum_9ef3c.jpg

Mace, R. (1997). What is Universal Design, The Center for Universal Design at North Carolina State University. Retrieved Retrieved November, 19.

Olguntürk, N. (2007). Evrensel Tasarım: Tüm Yaşlar, Farklı Yetenekler ve Çeşitli İnsanlık Durumları İçin Tasarım, Dosya 04: Tasarım ve Özgürlük: Engelli Insanlar ve Herkes İçin Tasarım, TMMOB Mimarlar Odası Ankara Şubesi, Bülten 46, 10-17. Erişim Adresi (12.01.2021): https://www.researchgate.net/publication/322775610_Yaslilik_Yasam_Cevresi_ve_Evrensel_T asarim

Sayar, G., Arat, Y. (2017). İmaj Yapı Tasarımında Evrensel Tasarım İlkelerinin Rolü; Konya Bilim Merkezi Örneği. Mühendislik Bilimleri ve Tasarım Dergisi, 5, 145-155. Erişim Adresi (12.01.2021): https://dergipark.org.tr/tr/pub/jesd/issue/29265/313337

Şenel, S., Şenel, H. ve Günaydın, S. (2019). Herkes İçin Mobil Öğrenme: Mobil Uygulamaların Evrensel Tasarım İlkelerine Göre İncelenmesi. Ankara Üniversitesi Eğitim Bilimleri Fakültesi Özel Eğitim $\begin{array}{lllll}\text { Dergisi, } & 20 & \text { (1), 73-92. } & \text { Erişim } & \text { (10.01.2021): }\end{array}$ https://dergipark.org.tr/tr/pub/ozelegitimdergisi/issue/43605/377503

Tandoğan, O. (2017). Evrensel Tasarım Kavramı ve Kentsel Peyzaj ile ilgili Örnekler Üzerinden Değerlendirilmesi, Artium Dergisi, 5 (2), 51-66. Erişim Adresi (11.01.2021): http://artium.hku.edu.tr/tr/download/article-file/338716 